Onder redactie van:

Prof. mr. dr. B.M.E.M. Schols

Prof. mr. dr. W. Burgerhart

Prof. mr. dr. F.W.J.M. Schols

Mr. F.M.H. Hoens

Mr. G.A. Tuinstra

Mr. J.Th.M. Diks

Mr. M.J.P. Schipper

Mr. dr. N.V.C.E. Bauduin

Mr. E.C.E. Schnackers

Mr. dr. J.W.A. Rheinfeld

\section{Advotip}

Erfrecht voor de advocaat

\title{
Pensioencijfers: wie heeft tweedepijlerpensioen, en het pensioenbewustzijn van de Nederlander
}

Het Nederlandse pensioenstelsel wordt van oudsher onderverdeeld in drie pensioenpijlers: het pensioen van overheidswege is de eerste pijler (AOW, Anw), het aan het werknemerschap gerelateerde pensioen is de tweede pijler en in de derde pijler zitten de 'overige' individueel getroffen (aanvullende) pensioenvoorzieningen.

Het pensioen in de tweede pijler valt uiteen in een ouderdomspensioen en een nabestaandenpensioen. Dit laatste bestaat zelf ook weer uit twee componenten, te weten het partnerpensioen en het wezenpensioen. Beide laatste pensioensoorten keren uit als de pensioendeelnemende partner is overleden en kunnen derhalve van essentieel belang zijn om de nabestaanden goed verzorgd achter te laten. Vandaag aandacht voor een drietal onderzoeken met enige cijfers over het pensioen in Nederland.

Allereerst de constatering dat zzp'ers en andere zelfstandigen die geen pensioen opbouwen in de tweede pijler zelf hun oudedagsvoorziening en nabestaandenverzorging moeten regelen, en wel in de derde pijler. En zoals u weet, heeft zowel de Pensioenwet (PW) als de Wet verevening pensioenrechten bij scheiding (Wvps) geen betrekking op het derdepijlerpensioen. Dit betekent dat bij scheiding niet wordt verevend en dat na het overlijden geen (bijzonder) partnerpensioen wordt uitgekeerd.

Anders dan wellicht wordt gedacht, bouwt niet iedereen die in loondienst is tweedepijlerpensioen op. Het eerste onderzoek dat vandaag aan bod komt bevat de meest recente CBS-cijfers over de omvang van deze groep, ook wel aangeduid als 'de witte vlek'.

Onderzocht zijn alle werknemers van 21 jaar tot de AOW-leeftijd (in de onderzoekspopulatie: 65 jaar en 6 maanden) die op 23 december 2016 een baan in loondienst hadden. Uit de CBS-cijfers bleek dat van een totale werknemerspopulatie van iets meer dan 6,5 miljoen personen, 13 procent kan worden gekwalificeerd als 'witte werknemer'. Dat wil zeggen een werknemer zonder actieve pensioenaanspraken of een werknemer met actieve pensioenaanspraken met een opgebouwd pensioenbedrag van $€ 0$. Binnen de witte werknemers bestaat nagenoeg geen verschil tussen mannen en vrouwen: 14 procent van de mannelijke werknemers en 12 procent van de vrouwelijke werknemers verwierf geen tweedepijlerpensioen. 
Het is de vraag of deze 'witte-vlekkers' er voldoende van zijn doordrongen dat niet alleen de 'goed verzorgde oude dag', maar ook de bescherming bij overlijden op henzelf aankomt.

In dat kader is het zinvol om een andere bron erbij te pakken en enkele recente cijfers over het pensioenbewustzijn van de gemiddelde Nederlander te bekijken. De eerste set cijfers is ontleend aan de Pensioenmonitor 2016. De monitor is samengesteld in opdracht van 'Wijzer in Geldzaken' en maakt, waar mogelijk, een vergelijking met de cijfers over 2014. Hieronder een deels letterlijke en deels geparafraseerde weergave van enkele wetenswaardigheden.

Opmerkelijk is dat steeds minder mensen aangeven goed op de hoogte te zijn van het pensioenstelsel in Nederland. In 2014 was dit nog 32\%, in 2016 is dit gedaald naar 26\%. Een cijfer dat in het algemeen, en in het bijzonder voor de witte vlek, te denken geeft.

Meer toegespitst op het overlijden is evenzo verontrustend het aantal personen dat aangaf het begrip 'partnerpensioen' niet te kennen:

\section{Ruim twee op de vijf weten niet wat het partnerpensioen inhoudt. $18 \%$ heeft er nog nooit van gehoord}

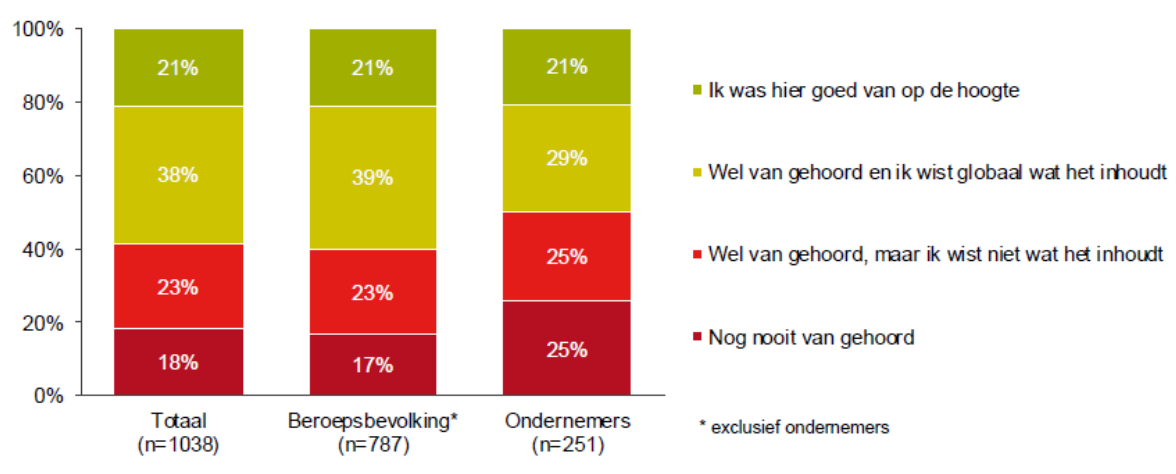

Zoals u weet, valt onder het partnerbegrip in de PW ook de ongehuwde partner. De precieze criteria en voorwaarden waaraan moet zijn voldaan, wil men kwalificeren als ongehuwde pensioenpartner, worden door ieder fonds zelfstandig bepaald. Een van de voorwaarden die in menig pensioenreglement wordt gesteld, is dat de pensioenpartner is aangemeld bij het fonds. Met dat in het achterhoofd komt de ongehuwde partner in de tweede pijler er op overlijdensvlak nog bekaaider vanaf als blijkt dat van de ondervraagde personen met een tweede pijlerpensioen $13 \%$ de partner niet heeft aangemeld bij die pensioeninstelling en $7 \%$ niet wist of was aangemeld.

Partner aangemeld bij eigen pensioenfonds/-verzekeraar

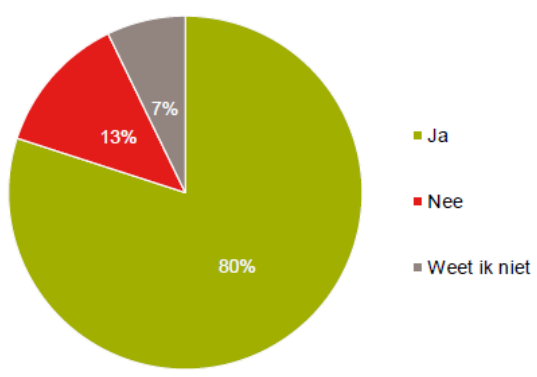


En van de ondervraagden was circa $25 \%$ zelf niet aangemeld bij de pensioeninstelling van de partner, en wist $19 \%$ niet of dit het geval was.

Zelf aangemeld bij pensioenfonds/-verzekeraar van partner

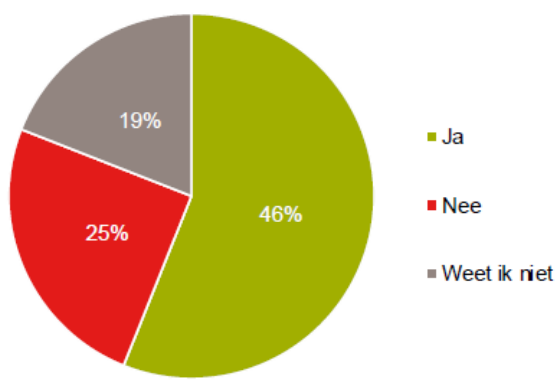

Uit beide grafieken rijst het beeld op dat de langstlevende partner er ook in de tweede pijler niet florissant voor staat. Een beeld dat wordt versterkt als men weet dat bijna $40 \%$ van de beroepsbevolking geen idee heeft wat een partnerpensioen is of er nog nooit van heeft gehoord. Bij ondernemers ligt dit percentage overigens rond de 50\%.

Ook een ander pensioenonderzoek, en wel één in opdracht van Aegon (en uitgevoerd door Motivaction) ten behoeve van een op 1 februari jl. tezamen met de VU georganiseerd congres, geeft een vergelijkbaar beeld.

Ook uit dit onderzoek blijkt dat voor de 'gemiddelde' Nederlander kennis over het partnerpensioen geen automatisme is:

\section{Het begrip partnerpensioen behoeft uitleg}

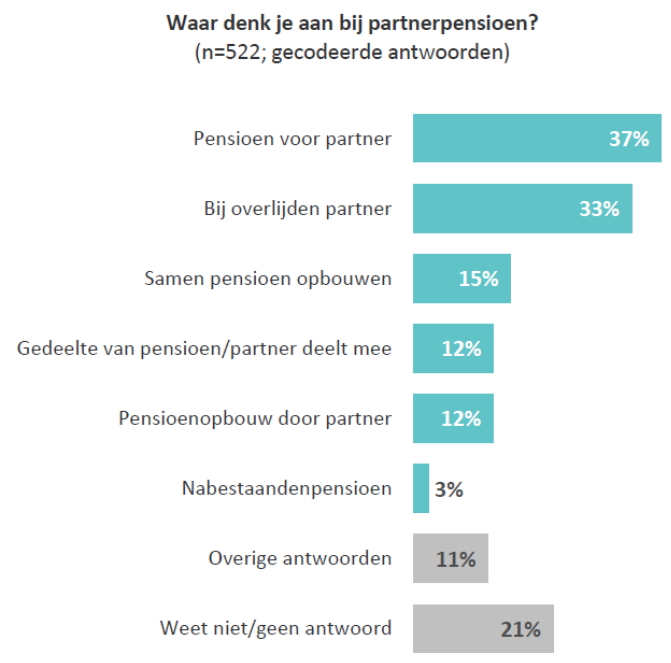

Het begrip partnerpensioen spreekt niet voor zich, zo blijkt uit de antwoorden op de open vraag 'waar denk je aan bij partnerpensioen'. Eén op de vijf Nederlanders met een partner geeft aan niet te weten wat er onder verstaan wordt.

Onder laagopgeleiden met een partner weet zelfs ruim 4 van de $10(44 \%)$ niet wat partnerpensioen is.

Het zijn vooral mensen die verwachten dat zij zelf of hun partner over onvoldoende inkomen beschikt wanneer één van beide de partners komt te overlijden, die van dit begrip niet op de hoogte zijn.

Wanneer wordt gevraagd of de eigen pensioenregeling een partnerpensioen kent, en hoe/wat dan precies is geregeld, wordt als volgt geantwoord: 


\section{Zekerheid dat men een nabestaandenregeling heeft, geeft motundtung}

\section{rust over voldoende inkomen na overlijden partner}

4 op 10 in het ongewisse over opbouw nabestaandenpensioen

Is er bij de pensioenregeling die je hebt bij je werkgever ook iets geregeld voor nabestaanden? $(n=522)$

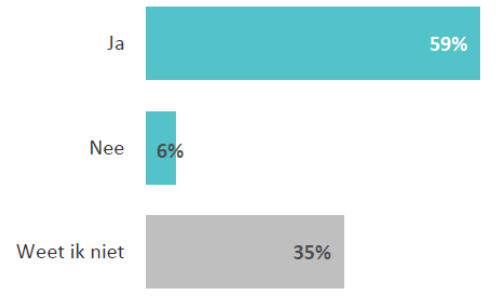

6 op de 10 Nederlanders met een partner geeft aan dat de pensioenregeling, waar hij via de werkgever aan deelneemt, voorziet in een regeling voor nabestaanden. Het is de vraag in hoeverre deze mensen echt op de hoogte zijn van wat er geregeld nu precies geregeld is. Bij de vraag naar de betekenis van het woord partnerpensioen noemt $39 \%$ van deze groep 'overlijden partner'.

\begin{abstract}
Nagenoeg de helft van de Nederlanders onder de 45 jaar (47\%) heeft er geen idee van of hun pensioenregeling voorziet in een regeling voor nabestaanden. Naarmate men ouder is, is men hier beter van op de hoogte. Ruim twee derde van de 45 tot 55 -jarigen $(69 \%)$ en driekwart van de ouderen vanaf 55 jaar zijn hier wel van op de hoogte en geven aan dat de regeling hier in voorziet.

We zien een verband tussen de verwachting onvoldoende inkomen te hebben bij het overlijden van de partner en onbekendheid met een nabestaandenregeling als onderdeel van de pensioenregeling bij de eigen werkgever. Mensen die in deze situatie zelf rond kunnen komen (of hun partner) zeggen vaker dat er iets geregeld is voor de nabestaanden.
\end{abstract}

Ook de cijfers over de beperkte kennis over de financiële gevolgen van het eigen overlijden voor de partner geven te denken:

\section{Over de financiële gevolgen van overlijden voor de partner motivation tast men in het duister}

\begin{abstract}
Meer dan de helft van de mensen met een partner die pensioen opbouwen, weet niet wat overlijden financieel betekent voor de achtergebleven partner. Dit geldt voor nagenoeg driekwart (71\%) van de laagopgeleiden en ook voor driekwart van de mensen die niet weten of er in hun pensioenregeling iets is geregeld voor de nabestaanden.

De overigen lopen het gevaar zichzelf rijker te rekenen dan wat het in werkelijkheid zal zijn. Met name mensen wel weten dat er in de pensioenregeling iets is geregeld voor nabestaanden (30\%), zijn van mening dat de partner bij het overlijden $70 \%$ van zijn of haar laatstverdiende salaris zal ontvangen.

Mensen die niet voldoende inkomen denken te hebben als hun partner overlijdt, of waarvan de partner niet voldoende inkomen zou hebben, weten deze vraag niet te beantwoorden.
\end{abstract}

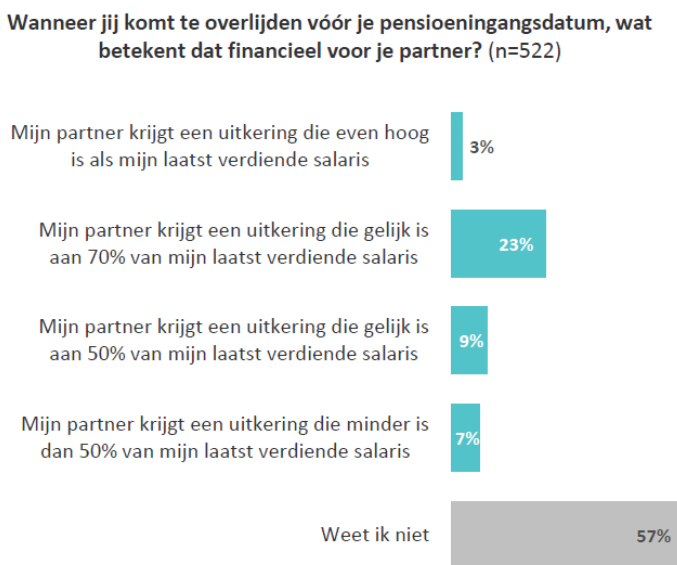

Onrustbarend: het merendeel heeft geen idee wat de financiële gevolgen zijn van het eigen overlijden. Maar er is meer. Zoals net al gemeld, wisselen per fonds de precieze criteria en voorwaarden voor de ongehuwde pensioenpartner. Een gevolg hiervan is dat, bijvoorbeeld, een 'pensioenfondswissel' verlies van de status 'pensioenpartner' kan betekenen. Dat een dergelijk verlies flinke gevolgen kan hebben bij overlijden, spreekt voor zich. De volgende grafiek geeft inzicht in de bekendheid van de gemiddelde Nederlander met een en ander: 
Het begrip 'partner' binnen partnerpensioen wordt divers ingevuld mativinticon

In welke van de onderstaande situaties ben je volgens de

wet een partner, als het om partnerpensioen gaat? $(n=522)$

Als je getrouwd bent

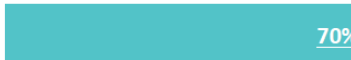

Als je samenwoont en geregistreerd partnerschap hebt

Als je in het verleden getrouwd bent geweest (en daarna gescheiden)

Als je bij je werkgever aangeeft dat je een partner hebt

$21 \%$

Als je samen langer dan 6 maanden op 1 adres staat ingeschreven (zonder notaris-akte)

Als je deel uitmaakt van een gezin (dus ook als kind)

Weet ik niet
1 op de 9 Nederlanders met een partner en een baan waar hij of zij pensioen opbouwt, geeft aan de vraag wat volgens de wet een 'partner' is als het gaat om partnerpensioen, niet te kunnen beantwoorden. $7 \%$ denkt dat het ook hier om kinderen uit het gezin gaat.

Opvallend is het hoge aantal mensen dat meent dat je partner volgens de wet bent, wanneer je dat zo doorgeeft aan je werkgever. Doe je dit niet, dan impliceert dat waarschijnlijk dat gedacht wordt, dat er ook geen partnerpensioen wordt opgebouwd.

De mensen die niet weten dat ze hun partner aan de werkgever moeten doorgeven, vullen bij deze vraag vaker 'weet niet' in (25\%). Vergeleken met de mensen die hun partner wel aan de werkgever hebben doorgegeven, weten eerstgenoemden minder vaak het juiste antwoord (de eerste 2 opties). Ook jongeren ( $t / \mathrm{m} 34$ jaar) weten minder vaak het juiste antwoord te geven.

Vooral uit de toelichting, rechts naast de diagrammen, blijkt dat in ieder geval 'de praktische toepasbaarheid' van de kennis over het pensioenpartnerbegrip te wensen overlaat. Wat men verder van deze cijfers en onderzoeken ook moge vinden, het lijkt hoe dan ook zonneklaar dat het partnerpensioen als verzorgingsinstrument na overlijden meer aandacht behoeft.

\section{Tot de volgende keer!}

Mr. F.M.H. Hoens

Radboud Universiteit Nijmegen

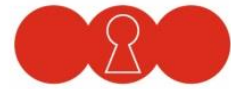

ScholsBurgerhartSchols

www.scholsburgerhartschols.nl

\section{Boomjuridisch}

\author{
Postbus 85576 \\ 2508 CG Den Haag
}

$\mathrm{T}(070) 3307033$

E info@boomjuridisch.nl

I www.boomjuridisch.nl 